\title{
Searching for a Biblical Worldview: From an Ecofeminist Theological Perspective
}

\author{
Ioanna Sahinidou ${ }^{1}$ \\ ${ }^{1}$ Wales University Trinity Saint David, 16 Lazeon str, 11741 Athens, Greece. \\ Correspondence: Ioanna Sahinidou, Wales University Trinity Saint David, 16 Lazeon str, 11741 Athens, Greece.
}

Received: May 4, 2015

Accepted: May 19, 2015

Available online: August 4, 2015

doi:10.11114/ijsss.v3i5.1003

URL: http://dx.doi.org/10.11114/ijsss.v3i5.1003

\begin{abstract}
The paper draws from my doctoral thesis (Sahinidou I., 2014) ${ }^{1}$. I make my case for an Christological perichoresis as an evolutionary step further in the direction of ecofeminist theology. God is present in all things by virtue of their being created. A few discussed paradigms by theologians help us see whether a non-anthropocentric biblical view, counter to dominion could be possible. If Gen. 1.26-28 is isolated, we may think that dominion is the normative biblical orientation for human-earth relations (Rasmussen, 2000). ${ }^{2}$ Yet, a theology of creation must be situated within the context of the entire Bible.

A holistic theology realizes that together with all beings, we must live responsibly. This perspective can evoke the religious sense that every being is valuable and that the whole forms a unity. A retrieved biblical, patristic, ecological view of the scheme of things and our place in it can be a call for us to know the world neither anthropocentrically, nor as isolated beings, but displace humans as the central goal of creation and re-position them as partners in its process. New science helps us realize our cosmic interrelated being and a sense of the whole (Eaton, 2005). ${ }^{3}$ The paper was presented during the Conference: ECOTHEE June 2015, Orthodox Academy of Crete.
\end{abstract}

Keywords: Anthropocentrism, dominion, Christology perichoresis, interrelatedness, creation.

\section{Introduction}

How did evil enter creation since God "saw all that he had made and it was very good (Gen. 1.31)? The verses "[Adam, said God] Cursed is the ground because of you" (Gen. 3.17b-18) tell us that the earth is cursed, after the fall because of humanity. What is creation's future? The verse Romans 8.20 "creation was subjected to frustration, not by its own choice but by the will of the one who subjected it, in hope that the creation itself will be liberated from its bondage to decay and brought into the glorious freedom of the children of God" brings hope for creation to be liberated along with the children of God.

\section{An Christological, Non Anthropocentric Worldview}

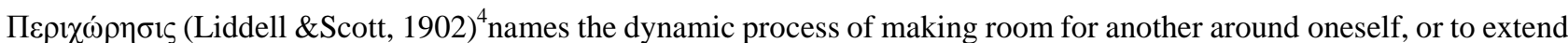
one's self round about. I focus on Christological Perichoresis that is the co-inherence in Christ of the human and divine natures for the bridge they build between the Creator and creation. Trinitarian inter-relationships go further than the cosmological scientific mode of relatedness, bearing an Christological message for wilful openness towards the 'other', when Logos was incarnated (Grey, 2003). ${ }^{5}$ I reclaim the patristic Christological use of perichoresis to show how we could bring together different entities, such as God and nature, look at them in unity, as the one person of Christ, and acknowledge the perichoresis between divine and human, divine and nature, while their identities are not confused. Christological perichoresis supports the idea that the whole of creation will be included in God's recreated cosmos responding to the redeeming power of Christ who became flesh, entering the web of life as a creature. In my doctoral

1 Sahinidou I. (2014). What Hope for the Suffering Ecosystems of our Planet? The Contextualization of Christological Perichoresis for the Contemporary Ecocrisis. Frankfurt: Peter Lang.

${ }^{2}$ Rasmussen L.L. (2000). Earth Community Earth Ethics. Maryknoll, New York: Orbis. p.229.

${ }^{3}$ Eaton H. (2005). Introducing Ecofeminist Theologies. New York: T \& T Clark International. pp.93-102.

${ }^{4}$ Liddell H \& Scott R. (1902). 'perichoreo' Dictionary of the Greek Language v. 3 L-P. Athens: Konstantinidis. p.570.

5 Grey M. (2003). Sacred Longings. London: SCM Press. pp.72-74. 
thesis, I defend an Christological, perichoretic non anthropocentric worldview that unites the temporal with the eternal, the divine with the cosmic, in Christ (LaCugna, 1993). ${ }^{6}$

The relations between the divine and fleshy natures of Christ permeate ineffably through not just human flesh. This becomes a key idea for theological anthropology undercutting ideas of human existence apart from the rest of creation (McFague, 1993). ${ }^{7}$ Realizing the Word as creator and re-creator of creation, a Christian scientist can recognize the task that can free nature from exploitation under modern technocratic cultures (Louth, 2004). ${ }^{8}$ We may discern and retrieve Christological perichoresis and the sense of the whole, lost in the mechanistic era. The relationship between created and uncreated is based on the 'union without confusion,' between divine and human natures in the one Christ incarnate (Bishop Kallistos Ware, 1998). ${ }^{9}$ Christological perichoresis can be an original starting point in perceiving both the economy of incarnation and resurrection that places perichoresis in the mystery of the communion between the trinity and the cosmos (LaCugna, 1993). ${ }^{10}$

Since Augustine, in the west theology emphasizes human uniqueness focusing the doctrine of redemption on the salvation of the human soul. The anthropocentric conception of salvation led to the exclusion of non-human creation from the vision of redemption realizing only humans as the object of divine cosmic concern (Northcott, 2004). ${ }^{11}$ Christian trinitarianism reveals for Christians and affirms for modern science, the sacred cosmic nature (Nesteruk, 2004). ${ }^{12}$ Our encounter with God in Christ is a renewal of ourselves so as to discern the will of God and follow it; it is a rebirth, not an intellectually gained knowledge (John 3.7-8).

\subsection{The human and the earth stories in Genesis 1}

A common place in the patristic texts is the belief that the Trinitarian God is imaged in the entire creation since creation is an icon of Godself (Keselopoulos, 2001); ${ }^{13}$ based on Romans 1.20: "since the creation of the world God's invisible qualities - his eternal power and divine nature - have been clearly seen, being understood from what has been made." The story of humans (Gen. 1.26-30) subduing earth violates the previous earth oriented story (Gen. 1.1-25). Within the earth story, no reason is given as to why a pristine earth revealed as a source of life and fertility had to be 'subdued'. Elohim finds earth as good. The story concerns the era before humans spoiled the pristine earth. The text moves from honouring earth as a geophany, to negating it as a force to overcome. Putting the text into context, we can see the narrator as living in the harsh Palestine environment and viewing the land as an alien force to be harnessed by hard work to produce food. We must recognize the intrinsic value of the earth and restore the earth story as a counterpart to the human story with which it interacts in $(\mathrm{Habel}, 2000)^{14}$ other stories in the Bible. The context makes a difference to exegesis. Psalm 8 from the context of Palestinian farming communes struggling to make a living in harsh conditions in a life style treading on the earth, can be read as inviting the poor farmer to take a wider view of creation and his part in it and glorify its creator. If the text is read from our own contexts, given our exploitative ecological footprint it justifies domination of nature (Grey, 2003). ${ }^{15}$

\subsection{God's Covenant with the Earth and the Entire Creation}

After the flood, the covenant is entered into the entire creation (Gen.9: 8-17). God said to Noah: 'I am establishing my covenant with you and your descendants to come and with every living creature that was with you,' 'I now set my bow on the clouds and it will be a sign of the covenant between me and the earth.' Israel received the land as a gift from God the caretaker: 'the land shall not be sold in perpetuity, for the land is mine; for you are only strangers and sojourners with me' (Lev.25: 23). Care for the earth, concern for the poor, sensitivity for both wild and farm animals, are met in Ex.10-2 and in Lev 25.4-7. All workers need rest:

the seventh year you shall let [the land] rest... the poor of your people may eat; and what they leave the wild animals may eat. You shall do likewise with your vineyards, and your olive orchard... you shall

\footnotetext{
6 LaCugna M. (1993). God for Us. New York: HarperSanFrancisco. pp. 270-4.

${ }^{7}$ McFague S. (1993). The Body of God. Minneapolis: Fortress Press., pp.105-6.

${ }^{8}$ Louth A. (2004). The Cosmic Vision of Saint Maximos the Confessor. Clayton \& Peacocke (Eds). ,In whom we Live and Move and Have Our Being. Grand Rapids, Michigan, Cambridge: William B. Eerdmans Publishing Company. pp.194-6.

${ }_{9}$ Bishop Kallistos (Ware) of Giokleia. (1998). Foreword. Sherrard, Christianity Lineaments of a Sacred Tradition. Brookline, Massachusetts: Holy Cross Orthodox Press. p.xix.

${ }^{10}$ LaCugna M. (1993). God for Us. New York: HarperSanFrancisco. pp.270-4.

11 Northcott M. (2004).Ecological Crisis and Environmental Ethics. In Lucas Vischer (ed.) Listening to Creation Groaning. Geneva: John Knox Series, 2004, p.212.

${ }^{12}$ Nesteruk A. V. (2004). The Universe as Hypostatic Inherence in the Logos of God. Philip Clayton \& Arthur Peacocke (ed.). In whom we Live and Move and Have Our Being. Grand Rapids, Michigan/Cambridge: William B. Eerdmans Publishing Company. p.183.

${ }_{13}^{13}$ Keselopoulos A. (2001). Man and the Environment. New York: St Vladinir's Seminary Press. p.22.

${ }^{14}$ Habel N. C. (2000). Geophany: The Earth Story in Genesis 1. In Habel N. C. (ed.), The Earth Story in Genesis. Sheffield: Sheffield Academic Press. pp.34-48,47-8.

${ }^{15}$ Grey M. C. (2003). Sacred Longings: Ecofeminist Theology and Globalization. London: SCM Press. pp.12-3.
} 
rest; your ox and your ass may have rest, and the son of your bondmaid and the alien may be refreshed. (RSV)

We now know about the environmental benefits of allowing land to lie fallow every few years, giving working and production animals a rest periodically and this also for laborers. We must consider the rotational grazing of livestock.

\subsection{The Wider Ecology of Creation}

Praise of God was not confined to humans alone. In Ps 148:1, 2-4, 7-12 the entire creation is invited to praise God. When we know humans as representatives of creation in front of God, we forget that any creature has its own voice to praise God.

A reading of the wisdom literature confirms the contention that the Genesis 1 account is not anthropocentric. God's response to Job places Job in the fragile economy of creation's world. Reading Job 38-40 next to Gen. 1.26-28 the sense of domination evaporates. Job as representative of humanity does not have the knowledge or power to rule any of creation's domains. The demands of justice must be located in the broader frontiers of God's freedom and love unknown to humans. God's speeches to Job reject an anthropocentric creation. God takes care of the creatures (Job 38.41, 39.1-3), having a bond with them. God places Job within the diversity of the life forms to find his place in creation as a member of a wider community, offering a cosmology where humans stand alongside all creatures (McDonagh, 1990). ${ }^{16}$ God challenges Job's cosmology because Job cannot account for all natural phenomena. The wild is full of mysteries unknown to us; creatures live independent of humans (Palmer, 1992) ${ }^{17}$ who are not God-authorised to rule over all creatures. Job is led into wider visions of wisdom. Redemption is the creation's healing and transformation; the realization of the life potential of all being; the celebration of the gift of life of a caring (Rasmussen, 2000) ${ }^{18}$ Creator, sustainer and redeemer of creation:

Who is this that darkens my counsel

with words without knowledge?...

Where were you when I laid the earth's foundation?.. (38.1-4)

Have you ever given orders to the morning

or shown the dawn its place. (38.12)

Have you journeyed to the springs of the sea

or walked in the recesses of the deep? (38.16)

Who fathers the drops of dew?

Look at the behemoth,

which I made along with you (45.15)

He ranks first among the works of God (40.19).

To renew our bond with the cosmic spheres of life (Abram, 1997) ${ }^{19}$, we need languages to show a cosmological phenomenon happening in an animate cosmos. A galaxy activates the dynamics of a cloud; 'listening' the cloud of hydrogen responds by making itself into stars. To say that hydrogen's quantum tendency is influenced by the waves passing through the cloud and a shock wave initiates a cloud's implosion, we describe events in a univocal physics-language. A metaphorical expression might be to say that the hydrogen 'listens' to the galaxy voices and responds by creating stars (Swimme \& Berry, 1992). ${ }^{20}$ 'Do we hear the heavens declaring the glory of God, the skies proclaiming God's work; the speech that the days and nights pour forth, displaying knowledge? Their voice goes out into all the earth'. (Psalm 19.1-6). 'Go to the ant, you sluggard, consider its ways and be wise. It has no commander, no overseer or ruler, yet it stores its provisions in summer and gathers its food at harvest.' 'ask the animals, and they will teach you, or the birds of

\footnotetext{
${ }^{16}$ McDonagh S. (1990). The Greening of the Church. Maryknoll, New York: Orbis. p.127,147-8,151.

17 Palmer C. (1992). Stewardship: A Case Study in Environmental Ethics. In Ian Ball et al. (eds), The Earth Beneath: A Critical Guide to Green Theology. London: SPCK. p.70.

18 Rasmussen L. L. (1996) Earth Community Earth Ethics. Maryknoll, New York, Orbis. pp.256-7.

19 Abram D. (1997). The Spell of the Sensuous. New York: Vintage. pp.138,179,273-4.

20 Swimme B. \& Berry T. (1992). The Universe Story. .New York: HarperSanFrancisco. p.43.
} 
the air and they will tell you; or speak to the earth, and it will teach you, or let the fish of the sea inform you. Which of all these does not know that the hand of the Lord has done this?'(Proverbs: 6:6-8. Job 12: 7-9).

In Deuteronomy 22.6 we read: 'If you come across a bird's nest beside the road, either in a tree or on the ground, and the mother is sitting on the young or on the eggs, do not take the mother with the young,' an analogy that speaks to environmental sustainability - human beings, can utilize the products of the world's ecosystems (the young birds), but not destroy the source (the mother bird) while developing societies.

\subsection{The Ecology of Creation in the NT}

In the parables, nature is included in Jesus' vision of liberation from oppression. God's kingdom is like a woman with yeast; or a mustard seed becoming a tree; or the birds that take shelter (Luke 13). Jesus compares growth to being pruned and tended like the vines (John 15.1-6); the lilies are a model for God's providence (Luke 12.28). Jesus' ministry was bedrock of a healed creation. He dealt with creation's natural phenomena. He revealed his glory by changing the water into wine (John 2.9); raising Lazarus from the dead (John 43.9); calming the storm (Luke 8.24).

The voice of the earth beings manifests itself in earth-languages of communication as sign, image, sound; it points to a reality embodied in nature as a hermeneutic tool to relate to the earth as kin (The Earth Bible Team, 2001). ${ }^{21}$ NT passages read in a perichoretic language show the Creator communicating with all the beings in distinct ways. Perichoretic languages express the interrelatedness of all that exist. Some paraphrased biblical verses: Jesus 'rebuked the wind and said to the waves, be still;' the waves responded to his words as living nature to its Creator 'and it wascalm'. 'The star, responding to Jesus' birth, went ahead stopping over the place where he was.' 'When Jesus gave up his spirit, the earth shook and the rocks split shocked. The tombs broke open and the bodies of many holy people who had died(Mark 4:9, Matthew 2:9, Matthew 27: 51) reacted bringing new life.'

\section{Epilogue}

Jesus' life, healings, miracles; engagement with animals are seeds of new creation (McDonough, 1990). ${ }^{22}$ The word for Adam from adamah-earth assumes a kinship of earth and humans. God's covenant with the earth, the voices of the other beings besides human that praise God, the inclusion of animals in sabbatical rest, restrictions on the use of mammals, the blood mammals share with us limit our rights to the lives of other beings (Ruether, 1999). ${ }^{23}$ A main contribution of ecofeminist theologies is that they stretch the limits of Christology and salvation toward ecological responsibility and a vision of cosmic salvation.

\section{References}

Abram, D. (1997). The Spell of the Sensuous. New York: Vintage.

Bishop Kallistos (Ware) of Giokleia. (1998). Foreword. Sherrard, Christianity Lineaments of a Sacred Tradition. Brookline, Massachusetts: Holy Cross Orthodox Press.

Eaton, H. (2005). Introducing Ecofeminist Theologies. New York: T \& T Clark International.

Grey, M. C. (2003). Sacred Longings: Ecofeminist Theology and Globalization. London: SCM Press.

Habel, N. C. (2000). Geophany: The Earth Story in Genesis 1. In Habel N. C. (ed.), The Earth Story in Genesis. Sheffield: Sheffield Academic Press.

Keselopoulos, A. (2001). Man and the Environment. New York: St Vladinir's Seminary Press.

LaCugna, M. (1993). God for Us. New York: HarperSanFrancisco.

Liddell, H., \& Scott, R. (1902). 'perichoreo' Dictionary of the Greek Language v. 3 L-P. Athens: Konstantinidis.

Louth, A. (2004). The Cosmic Vision of Saint Maximos the Confessor. Clayton \& Peacocke (Eds). In whom we Live and Move and Have Our Being. Grand Rapids, Michigan, Cambridge: William B. Eerdmans Publishing Company.

McDonough, S. (1990). The Greening of the Church. Maryknoll, New York: Orbis Books.

McFague, S. (1993). The Body of God. Minneapolis: Fortress Press.

Nesteruk, A. V. (2004). The Universe as Hypostatic Inherence in the Logos of God. Philip Clayton \& Arthur Peacocke (ed.). In whom we Live and Move and Have Our Being. Grand Rapids, Michigan/Cambridge: William B. Eerdmans Publishing Company.

Northcott, M. (2004).Ecological Crisis and Environmental Ethics. In Lucas Vischer (ed.) Listening to Creation

${ }^{21}$ The Earth Bible Team. (2001). The Voice of Earth: More than Metaphor? In Habel N. C. The Earth Story in the Psalms and the Prophets. Sheffield: Sheffield Academic Press.pp.23-8.

${ }^{22}$ McDonough S. (1990). The Greening of the Church. Maryknoll, New York: Orbis Books. pp.158-164.

${ }^{23}$ Ruether R. R. (1999). Gaia and God, an Ecofeminist Theology for Earth Healing. New York: HarperSanFrancisco. pp.19-22. 
Groaning. Geneva: John Knox Series.

Palmer, C. (1992). Stewardship: A Case Study in Environmental Ethics. In Ian Ball et al. (eds), The Earth Beneath: A Critical Guide to Green Theology. London: SPCK.

Rasmussen, L. L. (2000). Earth Community Earth Ethics. (2nd ed.) Maryknoll, New York, Orbis.

Ruether, R. R. (1999). Gaia and God, an Ecofeminist Theology for Earth Healing. New York: HarperSanFrancisco.

Sahinidou, I. (2014). What Hope for the Suffering Ecosystems of our Planet? The Contextualization of Christological Perichoresis for the Contemporary Ecocrisis. Frankfurt: Peter Lang.

Swimme, B., \& Berry, T. (1992). The Universe Story. .New York: HarperSanFrancisco.

The Earth Bible Team. (2001). The Voice of Earth: More than Metaphor? In Habel N. C. The Earth Story in the Psalms and the Prophets. Sheffield: Sheffield Academic Press.

\section{(c) $\mathbf{E Y}$}

This work is licensed under a Creative Commons Attribution 3.0 License. 